\title{
The Effect of Cooperative Problem Based Learning (CPBL) Model with Scaffolding on Students' Cognitive Learning Achievement of Eleventh Grade Science Class at Coastal Area in Yogyakarta
}

\author{
$1^{\text {st }}$ Citra Devi Imaningtyas \\ Science Education, Postgraduate \\ Program, Faculty of Teacher \\ Training and Education \\ Universitas Sebelas Maret \\ St. Ir. Sutami 36 A Surakarta \\ 57126, Indonesia \\ citradeviimaningtyas@gmail.com
}

\author{
$2^{\text {nd }}$ Suciati Suciati \\ Science Education, Postgraduate \\ Program, Faculty of Teacher \\ Training and Education \\ Universitas Sebelas Maret \\ St. Ir. Sutami 36 A Surakarta \\ 57126, Indonesia \\ suciati.sudarisman@yahoo.com
}

\author{
$3^{\text {rd }}$ Puguh Karyanto \\ Biology Education, Faculty of \\ Teacher Training and Education \\ Universitas Sebelas Maret \\ St. Ir. Sutami 36 A Surakarta \\ 57126, Indonesia \\ karyarina@yahoo.com
}

\begin{abstract}
This study aimed to determine the effect of CPBL model on students' cognitive learning achievement of eleventh-grade science class at the coastal area in Yogyakarta. This study was quasi experimental study. All of eleventh grade science class at the coastal area in Yogyakarta as population. Sampling technique using cluster random sampling included 172 students of three high schools as the representative region of east, middle, and west coastal area (SMAN 1 Panggang, SMAN 1 Srandakan, SMA Negeri 1 Temon). The assessing of students' cognitive learning achievement by using test instrument included 20 items on Digestive System material. Non-test technique uses observation method to determine the applicable syntax of CPBL model with scaffolding by using students' worksheet. Research design uses the pretest-posttest non-equivalent group design. Experiment class using CPBL model with scaffolding included:1) environmental provisions; 2) problem restatement and identification; 3) explaining, reviewing, and restructuring; 4) peer teaching synthesis and solution formulation; 5) developing conceptual thinking; 6) generalization, closure, and internalization. Control group using the expository method. Data were analyzed using t-test with significant $(5 \%)$. The results of the study showed CPBL model with scaffolding gave a positive effect on students' cognitive learning achievement $(0,00)$. Based on the results of the study can be concluded that CPBL model with scaffolding was influenced on students' cognitive achievement.
\end{abstract}

Keywords-CPBL model with scaffolding; students' cognitive achievement; coastal area

\section{INTRODUCTION}

The development of information and communication is the main characteristic of the $21 \mathrm{st}$ century and has the impact on learning paradigm [19]. [13] states that one of the demands of the globalization era is seeds compete in obtaining and utilizing information and also making decisions precisely. The 21 st century is an era that requires human resources who have critical thinking skills, creative thinking, collaboration, and meta-cognition. In addition, the 21 st century also demands ready-towork human resources and they have good ability to solve problems [24]. Globalization era changes have the impact on education. The most visible impact as a result those changes in the education world is the students' learning outcome which no longer refers to the understanding of the concept, but also must be accompanied by the mastery of 21 st century skills.

Learning achievement is the students' overall which reflects indicators of basic competence and the degree of behavior change [22]. Learning outcome can also be interpreted as something gained, ability, or value of the completion of learning [4]. Learning outcome includes three domains: cognitive, affective, and psychomotor. The cognitive domain relates to students' knowledge. The affective domain in another way relates to attitudes, and the psychomotor domain relates to student skills [7]. However, this research is limited to cognitive learning outcome only. Cognitive learning achievement can be a strong predictor of academic success [29]. The cognitive learning outcome has several characteristics including: 1) the existence of a new behavior change in form of actual capability; 2) the new capability stays for a long period of time; 3 ) and the new abilities are obtained through learning event [11].

The observation biological learning result in some schools in the Special Region of Yogyakarta (hereafter DIY) shows that teaching and learning process is still teacher-centered. The material delivery is delivered through the transfer of knowledge. Students also tend to be passive in the following 
Biology learning activities. Students find it difficult to answer oral questions given by the teacher about the previous material, they have to reopen the book to answer them. The result of observation on the previous material assessment shows that $30 \%$ of the students have not reached the passing grade (hereafter KKM). Not achieving KKM indicates that cognitive learning outcome has not been achieved maximally.

Environment can be a factor affecting student learning outcome. [14] argue that the learning environment is the most important factor influencing students' conceptual understanding and students' point of view. Personal factor or environmental factor can affect students' confidence level which influences student's learning style and can influence student learning outcome [26]. The socio-cultural background can also be one of the environmental factors that influence student learning outcome [13]. The better environment with a good socioeconomic condition, the better students' will be [2]. One of areas that have good social condition is the coastal area because of its diverse natural potential.

DIY is the coastal area which has much potential that can be utilized. The coastal area of Yogyakarta has good tourism potential. Besides that, some areas in coastal area of DIY have applied agriculture in sand area and the coastal area of DIY also have the potency of fishery resource which is good enough [25]. These potentials make the coastal area of Yogyakarta that is well managed by the local government, and its human resources to be the good socioeconomic characteristic.

Observation result in schools in the coastal areas of Yogyakarta shows less optimal cognitive learning outcome. The lack of maximum students' cognitive learning outcome can be due to the learning process that is still the nature of knowledge transfer. [8] states that acquiring knowledge in science learning should be the process of data collection through experiment and observation. One of the learning models that has the observation and experiment stage is the inquirybased learning model. Inquiry-based learning will facilitate students to be active in scientific activities, which will have an impact on improving student learning outcome [1].

CPBL learning model is one of the models that can be used as a solution of the problem - students' less maximal cognitive learning outcome. The CPBL learning model is a problem-based learning model that can train students to solve problems well that can indirectly improve students' cognitive, affective, and psychomotor abilities and can make students think divergently [27]. The CPBL learning model guides students in the process of solving problems with cooperative learning principles so that the whole class shapes the learning community [17], [16]. CPBL learning model developed based on constructivism ideology. The CPBL learning model has three main learning steps of learning covering: (1) Problem Restatement and Identification phase, (2) peer teaching synthesis and solution formulation phase, and (3) Generalization phase, Closure, and Internalization [15].

CPBL learning model has the advantage to improve students' thinking ability, communication ability, and interpersonal skills [10]. The activity of CPBL learning model also improves students' skills in the cooperative task [16]. The CPBL model supports students to think more extensively and can train students' problem-solving abilities [28]. CPBL learning model also has weaknesses: 1) the learning process of this model is quite burdensome because the students are given a lot assignments, duties, and responsibilities, [17]; 2) the implementation of the CPBL model needs a very long time and; 3 ) the majority of students find it difficult to follow the CPBL learning model early in the learning process [10]. The number of assignments and responsibilities and the difficulties occur at the beginning of learning make the implementation of CPBL model need help in form of scaffolding to reduce the difficulties.

[9] says that scaffolding can control the complexity of student problems that allow students to manage time to complete tasks at any time. Scaffolding complements the weaknesses of the CPBL learning model in order that the learning model can run smoothly and improve students' learning achievement. [31] defines scaffolding in learning as a gradual help from teachers that can be done through instruction, questioning, model demonstration, and other assistance to students. Scaffolding has three main stages including environmental provisions, explaining reviewing, restructuring, and developing conceptual thinking [12].

Based on the elaboration of the background of the problem, the researchers then conducted a study entitled "The Effect of Cooperative Problem Based Learning (CPBL) Model with Scaffolding on Students' Cognitive Achievement of Eleventh Grade Science Class at Coastal Area in Yogyakarta".

\section{RESEARCH METHODOLOGY}

This study is an experimental research aimed at figuring out the effect of the use of CPBL model with scaffolding on students' cognitive learning achievement. The population of this study is all eleventh-grade students of science class (hereafter XI IPA) at the coastal school of Yogyakarta. The sampling technique employed by the researchers is cluster sampling technique. This was chosen because the population was wide enough that is at the coastal area of the Special Region of Yogyakarta. Cluster sampling technique is used to determine the sample if the population is available in form of clump units in the population [30]. The sample taken in this research is 172 students of XI IPA from 3 different schools 
representing the coastal area of east, middle and west part of Yogyakarta. They are: state senior high school (hereafter SMA Negeri) 1 Panggang, Gunung Kidul, SMA Negeri 1 Srandakan, Bantul, and SMA Negeri 1 Temon, Kulon Progo.

The instrument used to measure students' cognitive achievement is by using test. The test consists of 20 questions on digestive system material. Meanwhile, the non-test technique employed by the researchers is observation. It is used to determine the applicable syntax of CPBL model with scaffolding by using students' worksheet. Non-test instruments used include students' learning worksheets, students' scaffolding worksheets, lesson plans, and observation sheets.

The research design in this research is the pretestposttest design. The research design of pretestposttest control group design. The experiment group using CPBL model with scaffolding including: 1) environmental provisions; 2) problem restatement and identification; 3) explaining, reviewing, and restructuring; 4) peer teaching synthesis and solution formulation; 5) developing conceptual thinking; 6) generalization, closure, and internalization [18];[12]. The control class uses an expository model in learning.

This research is a quantitative research using t-test data analysis technique. The t-test is a test conducted to know the difference between two groups of the variable. The t-test is performed with the help of SPSS 21 application. The prerequisite test, however, must be run before testing hypothesis. They are the normality test-Kolmogorov Smirnov test, and the homogeneity test-Levene's test.

\section{RESULT}

Description of the daily test result on digestion material of Biology subject is shown in TABLE 1 .

TABLE I. DESCRIPTION DATA OF TEST RESULT OF BIOLOGY SUBJECT

Std.

Std. Error

\begin{tabular}{lllccc} 
& \multicolumn{1}{c}{ Group } & N & Mean & Deviation & Mean \\
\hline \multirow{2}{*}{ Pretest } & Experiment & 86 & 60,00 & 13,106 & 1,413 \\
\cline { 2 - 6 } & Control & 87 & 58,74 & 16,481 & 1,767 \\
\hline \multirow{2}{*}{ Posttest } & Experiment & 86 & 81,51 & 8,814 & .950 \\
\cline { 2 - 6 } & Control & 87 & 64,95 & 14.356 & 1.548 \\
\hline
\end{tabular}

Based on TABLE 1, it can be seen that there are 172 students used as the research subject. The average score obtained from the pretest results in the control class is 58.74 and then after given posttest, the average score increases to 64.95. The experimental class obtains 60 of the average score then after given treatment and run post test, it increases to 81.51. It is known that the control class score also increases in terms of learning achievement although it is not as significant as the experimental class.

Test conducted in this study is a test to know the effectiveness of CPBL model toward the students' cognitive learning achievement. Prior to hypothesis testing using the t-test, the prerequisite test was performed to ensure that the data obtained is normal and homogeneous. Table of normality test result is shown in TABLE II.

TABLE II. NORMALITY TEST RESULT

\begin{tabular}{ccc|c}
\hline Group & $\begin{array}{c}\text { Test } \\
\text { Statistic }\end{array}$ & $\begin{array}{c}\text { Asymp. Sig. } \\
\text { (2-tailed) }\end{array}$ \\
\cline { 1 - 2 } Experiment_Pre_Panggang & 0,167 & 0,052 \\
Experiment_Post_Panggang & 0,164 & 0.062 \\
Control_Pre_Panggang & 0,160 & 0,055 \\
Control_Post_Panggang & 0,145 & 0,125 \\
Experiment_Pre_Srandakan & 0,129 & 0,200 \\
Experiment_Post_Srandakan & 0,160 & 0,056 \\
Control_Pre_Srandakan & 0,133 & 0,200 \\
Control_Post_Srandakan & 0,168 & 0,057 \\
Experiment_Pre_Temon & 0,157 & 0,057 \\
Experiment_Post_Temon & 0,151 & 0,077 \\
Control_Pre_Temon & 0,155 & 0,055 \\
Control_Post_Temon & 0,152 & 0,066 \\
\hline
\end{tabular}

Based on Table III it is known that Fscore is 21.044 and the significance is 0.00 . The homogeneous data is if the Levene's test significance value is greater than 0.05 . The Levene's significance test significance score is greater than 0.05 so it can be concluded that the data are homogeneous.

Hypothesis testing can be performed after the prerequisite test is met. Data analysis was done by using t-test. The t-test above aims to know the difference between student score in the control group and the experimental group. The level of significance used in hypothetical decision making is $(\alpha=0,05)$. If the probability significance ( $\mathrm{sig}$ ) is $<0.05$, then the null hypothesis (H0) is rejected and if the probability significance $(\mathrm{sig})$ is $>0.05$ then the null hypothesis is accepted. The calculation result is shown in TABLE III.

TABLE III. HOMOGENITY TEST RESULT

\begin{tabular}{cccc} 
& Group & F & Sig. \\
\hline Posttest & Equal & 21.044 & .000 \\
& variances & & \\
assumed & & \\
& Equal & & \\
& variances not & \\
& assumed \\
\hline
\end{tabular}


Based on Table III it is known that Fscore is 21.044 and the significance is 0.00 . The homogeneous data is if the Levene's test significance value is greater than 0.05 . The Levene's significance test significance score is greater than 0.05 so it can be concluded that the data are homogeneous.

Hypothesis testing can be performed after the prerequisite test is met. Data analysis was done by using t-test. The t-test above aims to know the difference between student score in the control group and the experimental group. The level of significance used in hypothetical decision making is $(\alpha=0,05)$. If the probability significance ( $\mathrm{sig}$ ) is $<0.05$, then the null hypothesis $(\mathrm{H} 0)$ is rejected and if the probability significance (sig) is $>0.05$ then the null hypothesis is accepted. The calculation result is shown in TABLE IV.

TABLE IV. T-TEST TEST INDEPENDENT TEST RESULT

\begin{tabular}{|c|c|c|c|c|c|c|c|c|c|}
\hline & \multicolumn{2}{|c|}{$\begin{array}{c}\text { Levene's Test for } \\
\text { Equality of } \\
\text { Variances } \\
\end{array}$} & \multicolumn{6}{|c|}{ t-test for Equality of Means } \\
\hline & & \multirow[b]{2}{*}{$\mathrm{F}$} & \multirow[b]{2}{*}{ Sig. } & \multirow[b]{2}{*}{$\mathrm{t}$} & & \multirow{2}{*}{$\begin{array}{l}\text { Sig. } \\
(2- \\
\text { tailed })\end{array}$} & \multirow{2}{*}{$\begin{array}{c}\text { Mean } \\
\text { Difference }\end{array}$} & \multirow{2}{*}{$\begin{array}{l}\text { Std. Error } \\
\text { Difference }\end{array}$} & $\begin{array}{c}95 \% \\
\text { Confidence } \\
\text { Interval of the } \\
\text { Difference } \\
\end{array}$ \\
\hline & & & & & Df & & & & Lower Upper \\
\hline \multirow[t]{2}{*}{ Posttest } & $\begin{array}{c}\text { Equal } \\
\text { variances } \\
\text { assumed } \\
\end{array}$ & 21.044 & .000 & 10.375 & 170 & .000 & 16.558 & 1.817 & $12,972 \quad 20.144$ \\
\hline & $\begin{array}{c}\text { Equal } \\
\text { variances } \\
\text { not } \\
\text { assumed }\end{array}$ & & & 10.392 & 141,110 & .000 & 16.558 & 1.817 & $12,967 \quad 20.149$ \\
\hline
\end{tabular}

Based on TABLE IV it can be seen that the significance score obtained is 0,000 which means that the significance score is smaller than 0.05 . From that data, it can be concluded that H0 is rejected. Therefore, it can be said that there is a significant difference of the average score of both control and experiments group after being given the treatment in which the average score control group posttest is 64,95 and 81,51 for the experiment group.

\section{DISCUSSION}

Based on the data analysis, it is found that CPBL model with scaffolding has the effect on students' achievement result of cognitive learning. The CPBL model demands that students not only listen, write and record. CPBL has the advantage of demanding active students to think, communicate with friends and use all their potential to think as much as possible and construct their own knowledge [5]. Scaffolding in the learning process was done as a complement of the weakness of CPBL learning model. Based on previous research, it is known that CPBL learning model is a model that burden students with many tasks, responsibilities and, it is said also that the CPBL model is difficult for students at the beginning of learning [10]. The weakness of the CPBL learning model is then overcome by the use of scaffolding. Scaffolding can control the complexity of student problems that allow students to manage time to complete tasks at any time [9]. The scheme of the combination process of the CPBL syntax with scaffolding steps is presented in FIG 1.

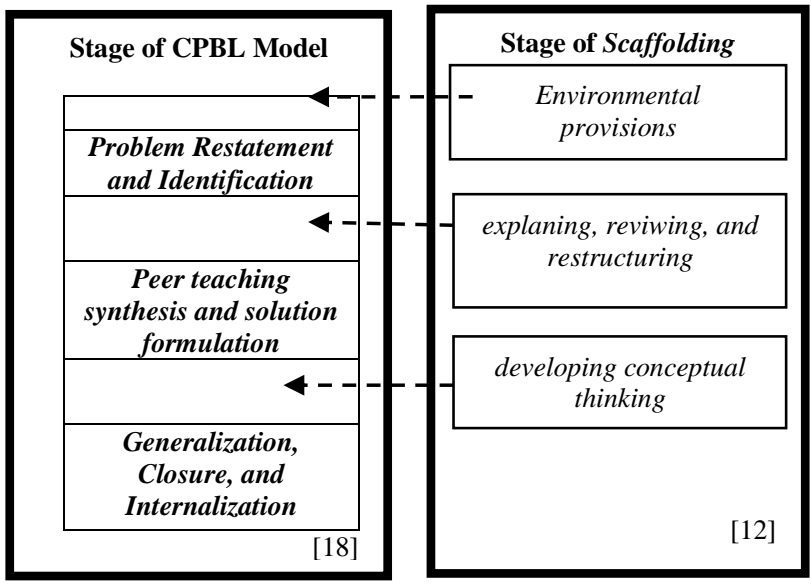

Fig 1.The scheme of the combination process of the CPBL syntax with scaffolding steps 
CPBL with scaffolding has a syntax that can support the improvement of student learning achievement, CPBL syntax with scaffolding covering 6 stages: 1) environmental provisions; 2) problem restatement and identification; 3) explaining, reviewing, and restructuring; 4) peer teaching synthesis and solution formulation; 5) developing conceptual thinking; 6) generalization, closure, and internalization [18], [12].

The first syntax in CPBL learning with scaffolding is environmental provisions. Enviromental provisions are part of the scaffolding stage used to examine the extent to which students have knowledge [12] This initial test phase is used to determine the type, shape, and intensity of scaffolding provided in the learning process. Environmental provisions are needed, since scaffolding is essentially teachers' assistance. It is then gradually adapted to the students' abilities and the assistance is reduced until students can be responsible on their own [20]. If only the environmental provision process the students are able to take their responsibility, the scaffolding process of the next stage is no longer needed.

The second syntax in CPBL learning with scaffolding is the stage of problem restatement and identification. This stage is the first part in the CPBL learning model. This stage is the stage where the students find the problem. Restatement and identification phases can be subdivided into 3 stages. The first stage is the discovery of individual problems beyond learning. This stage is done outside the learning activity. Before the class begins, the students individually prepare the problems based on the phenomena that the teacher has given before. At this stage, the student prepares the lesson personally so that the group discussion is expected to be productive since all children express their opinions about the result of problem identification in the discussion forum [18]. After formulation of individual problems stage, group discussions are conducted to provide confidence for students to voluntarily convey opinions in groups [23]. After the group discussion is completed then a class discussion is held. [16] argues that the formulation of the problem is made in form of questions rather than statements. This leads the students to find solutions to the problems.

The third syntax is explaining, reviewing, and restructuring. This third stage contains three main activities. The explaining stage begins with checking the truth of the students' answers at the previous CPBL learning stage, if the student is not yet able to answer nor understand the previous stages, then the teacher asks directive questions to the that they can answer and understand the concept correctly. The reviewing stage is the stage of the group discussing until to find and correct the mistakes. The last stage is the restructuring stage. At this stage, the students must reconstruct the correct answer [12]
The fourth syntax of the CPBL model with scaffolding is peer teaching synthesis and solution formulation. This stage requires the students to prepare knowledge, idea, or concept. This stage helps students to construct their own knowledge by guiding them in search of important concepts and information from related sources then explaining what is understood and informing what is poorly understood in group discussion [28]. At this stage, the task collected by the group is a report which is the result of settlement of the problems which the group has chosen [18]. Cognitive process at this stage is done individually, in the process of searching ideas, knowledge and concepts. They are also done in a group by doing peer teaching. Peer teaching helps them to solve problems that are difficult to solve individually [10]. This phase trains students to eliminate knowledge gaps between group members before solving problems. The end result of the second stage is the learner can work together to eliminate knowledge gaps within group members and then the side is able to create and apply the owned to solve the problem [15].

The fifth syntax is developing conceptual thinking. Developing conceptual thinking is the stage of discussion of student answers. Besides that, at this stage discussion of alternative search answers is also conducted so that students can find other concept related to the problem [12]. This scaffolding stage prepares students to continue the next CPBL stage.

The sixth syntax is generalization, closure, and internalization. This syntax requires students to present the final solution in front of the class. At this stagem the teacher reviews and gives comment to prevent misconception and to strengthen the understanding of students' knowledge [32] This stage also requires students to summarize the important concepts of the proposed problem and internalize the concept into new knowledge.

Each stage in CPBL learning always involves students 'cognitive abilities that influence students' cognitive learning achievement. CPBL model is quite difficult and enough to burden the students with a lot of responsibility, but CPBL also can develop the curiosity of students and make students have the willingness to learn, in addition, CPBL also avoids learning that is the transfer of knowledge [10]. CPBL weakness can also be overcome by the scaffolding at each stage of CPBL. Scaffolding is a tool, strategy, and guidance that supports students to achieve a higher level of understanding that students cannot understand without help [6].

Many factors can affect student learning achievement. It is not only influenced by the learning process in the classroom, but also influenced by environmental factors. The socio-cultural background becomes one of the environmental factors that influence students' learning achievement. The better socioeconomic, the better students' achievement will 
be [2]. Socioeconomic conditions have a positive influence on student learning achievement because of the role of economic impact on the completeness of infrastructure facilities [2]. Socioeconomic conditions also affect parenting patterns.

DIY has the great potential of coastal resources with different spatial characteristics in accordance with the landscape. The coastal areas of Yogyakarta include several areas including mangroves, coral reefs, settlement areas, marine and terrestrial fisheries, sandy farming areas, and tourism areas [25]. Coastal areas may have high natural and wealth potential but the students' learning acheivement is still low. It is proven from the documentation of students' daily test that they have not reached KKM. This proves that students' cognitive learning achievement can be maximized if all the factors that affect the learning achievement are empowered both the environmental factors and the learning process factors.

\section{CONCLUSION}

Based on the hypothesis test result, it can be concluded that there is a positive and significant effect of the implementation of Cooperative Problem Based Learning model with Scaffolding on students' cognitive learning achievement XI MIPA at the coastal area, Special Region of Yogyakarta. This is supported by the result of t-test with $5 \%$ significance level which shows that the value of significance is less than 0.05 so it can be said there is a significant difference on the average score of both control class and experiments group after given treatment. In addition, the average score of control and experiment group are 64.95 and 81.6. Learning achievement can be influenced by many things including, learning environment in the classroom related to the learning method and the existence of environmental factors such as economic factors, education level of their parents and school environment. Learning science at school should be student-centered and processoriented that can facilitate investigation activities and student learning independence. They will have a positive impact on cognitive learning achievement. For further research, it is best to look for studentcentered learning innovations that can empower students' cognitive learning achievement.

\section{ACKNOWLEDGMENT}

The researchers would like to express their gratitude to the supervisors of Post Graduate Program of Science Education on Biology Major of Sebelas Maret University, who have given guidance and participated in the research process. The researchers would also to like to say thank you to all parties involved in this research, the school principals, the Biology teachers, peers and students who have worked well together during data collection in the field.

\section{REFERENCES}

[1] A, Abdi. "The Effect of Inquiry-based Learning Method on Students' Academic Achievement in Science Course", Universal Journal Of Educational Research, vol. 2(1), pp. 3741, 2014.

[2] A. Barr, J. Burns, L. Miller, \& L. Shaw.” Economic status and acknowledgement of earned entitlement. Journal of Economic Behavior and Organization", pp. 1-30, 2015.

[3] A. Diniz, M.D. Pocinho, \& L.S. Almeida. "Cognitive abilities, sociocultural background and academic achievement". Psicothema , vol. 23 (4), pp. 695-700, 2011.

[4] A. J. Nitko, "Educational Assesment of Students", (Colombia Ohio: Merril Prentice Hill), p.22, 2001.

[5] A. Talib, \& I. B. Kailani, "Problem Based Learning in Cooperative Situation (PBLCS) and Its Impact on Development of Personal Intelligence". International Journal of Evaluation and Research in Education, vol. 3 (4), pp. 236244, 2014.

[6] A.B. Thomas \& W.S. John, "A Summary of Research Exploring Hard and Soft Scaffolding for Teachers and Students Using a Multimedia Supported Learning Environment". The Journal of Interactive Online Learning, vol. 1(2), pp. 1-12, 2002.

[7] B. S. Bloom, "Taxonomy of Educational Objectives". (New York; David Mc Kay Co, Inc), 1975.

[8] Carin \& Sund. "Teaching Science Through Discovery". (Merrill Publishing Company : New York), 1990.

[9] D. Wood \& H. Wood, "Contintgency in tutoring and learning". Learning and Instruction, Vol 6 (4), pp. 391-398, 1996a.

[10] F.M. Adi, F.A. Phang, \& K.M.Yusof, K. M. "Student Perception Change in a Chemical Engneering Class Using Cooperative Problem Based Learning (CPBL)". ProcediaSocial and Behavioral Sciences, vol. 56, pp. 627-635, 2012.

[11] G.E. Snelbecker "Learning Theory Instructional Theory and Psychoeducational Design". (New York : Mc Graw Hill Book Co), 1974.

[12] I. Anghileri "Scaffolding Practices That Enhance Mathematics Learning". Journal of Mathematics Teacher Education, vol. 9, pp. 33-52, 2006.

[13] I.W.Sadia."Pengembangan Kemampuan Berpikir Formal Siswa`SMA Melalui Penerapan Model Pembelajaran "Problem Based Learning" Dan "Cycle Learning" Dalam Pembelajaran Fisika". Jurnal Pendidikan dan Pengajaran UNDIKSHA, No. 1 TH, Januari 2007.

[14] J. D. H. M.Vermunt, \& F. A. W. M Van Rijswijk,. "Analysis and development of students' skill in self-regulated learning". Higher Education, vol. 17, pp. 647-582, 1988.

[15] K. M. Yusof, F.A. Phang \& S. A. Helmi, "How To Develop Engineering Students Problem Solving Skill Using Cooperative Problem Based Learning (CPBL)". World Congress on Engineering Education, pp. 2-8, 2013.

[16] K. Panlumlers, \& P. Wannapiroon, Design Cooperative Problem Based Learning Activities to Enhance Cooperation Skill in Online Environment. Procedia-Social and Behavioral Sciences ,vol. 174, pp. 2184-2190, (2015).

[17] K.M. Yusof, S.A Hasan, M. Z. Jamaludin, \& N. F. Harun,. "Cooperative Problem Based Learnuing (CPBL): Framework for Integrating Cooperative Learning and Problem-based Learning". Procedia-Social and Behavioral Sciences, vol. 56, pp. 223-232, 2012.

[18] K.M.Yusof, A.H. Syed., Z.J. Mohammad, \& F. H. Nor, "Cooperative Problem-Based Learning (CPBL) A Practical PBL Model For Engineering Courses". Ieee Global Engineering Education Conference (Educon) - Learning Environments and Ecosystems in Engineering Education, pp. 366-373, 2011.

[19] M. I. Farisi. "Developing the 21st Century Social Stidies Skills Through Technology Integration". Turkish Online Journal of Distance education (TOJDE), vol. 17(1), 2016. 
[20] M. Van Uum., R. Verhoeff., and M. Peeters, "Inquiry-Based Science Education: Scaffolding Pupil' Self-Directed Learning in Open Inquiry". International Journal of Science Educational, 2017 https://doi.org/10.1080/09500693.2017.1388940.

[21] M.Y. Khairiyah, A. H. Syed., Z. J.Mohammad, \& F. H. Nor, "Cooperative Problem-Based Learning (CPBL) A Practical PBL Model For Engineering Courses". Ieee Global Engineering Education Conference (EDUCON) - "Learning Environments and Ecosystems in Engineering Education", pp. 366-373, 2011.

[22] Mulyasa. "Kurikulum yang di sempurnakan". (Bandung: PT Remaja Rosdakarya), 2006.

[23] N. F. Jumari, K. M. Yusof, \& F. A. Phang, "Metacognitive Development in Engineering Student Through Cooperative Problem Based Learning (CPBL)". Engineering Education for Smart Society , pp. 107-120, 2018.

[24] Partnership for 21st Century Skills. "P21 framework definitions". 2009. Retrieved from http://www.p21.org/storage/documents/P21_Framework_Def initions.pdf

[25] Purwantara, Sugiharyanto \& K. Nurul, "Karakteristik Spasial Pengembangan Wilayah Pesisir Daerah Istimewa Yogyakarta Dalam Konteks UUK DIY”. Artikel Hibah Bersaing, 2015.

[26] S. Sugathan, D.S. Singh, A. S. Bakar, M.H. Azizan \& M. F. Nasarudin, "PERSONAL, Environmental And Lifestyle Factors Affecting Learning Among Medical Students: A
Cross Sectional Study". International Journal of Preventive and Therapeutic Medicine, vol. 3 (1), pp. 1-7, 2007.

[27] S.A. Gyako, "Use of Cooperative Problem Based Learning Model to Develop Creativity and Foster Democracy, and Improve Student Learning Outcomes in Chemistry at the NCE Level. Journal of Resourcefulness and Distinction", vol. 11 (1), pp. 1-12, 2015.

[28] S.A.. Hasan, K. M. Yusof., S. Mohamad, M.S. Abu, \& Z. Tasir, . "Methods to Study Enhancement of Problem Solving Skills in Engineering Student through Cooperative Problem Based Learning". Procedia-Social and Behavioral Science, vol. 56, pp. 737-746, 2012

[29] S.M. Magdalena, "The relationship of learning styles, learning behaviour and learning outcomes at the romanian students". Procedia - Social and Behavioral Sciences, vol. 180, pp. 1667-1672, 2015.

[30] Sugiyono. "Metode Penelitian Pendidikan (Pendekatan Kuartitatif,. Kualitatif dan R\&D)". (CV. Alfabeta: Bandung), 2012.

[31] T. L. Harris \& R. E. Hodges, "The literacy dictionary: The vocabulary of reading and writing, Newark", (DE: International Reading Association), 1995.

[32] U. S. Radzali, K. M.Yusof, \& F.A. Phang,." The Effectiveness Of Cooperative Problem-Based Learning (CPBL) Towards Lecturer's Conducted". http://www.pmo.gov.my/dokumenattached/NEM_Report_I.p df. , pp. 1-7, 2011. 